\title{
Influence of selection for egg production on egg quality traits in Japanese quail
}

\author{
Mahmoud M. El-Attrouny \& Mahmoud M. Iraqi \\ Department of Animal Production, Faculty of Agriculture, Benha University, Moshtohor, Toukh 13736, Qalyubia, Egypt
}

(Received 10 July 2020; Accepted 11 December 2020; Published 1 February 2021)

\begin{abstract}
Copyright resides with the authors in terms of the Creative Commons Attribution 4.0 South African License.
See: http://creativecommons.org/licenses/by/4.0/za

Condition of use: The user may copy, distribute, transmit and adapt the work, but must recognize the authors and the South African Journal of Animal Science.
\end{abstract}

\begin{abstract}
The current study investigated the influence of selection for increased egg production on external and internal egg quality traits over five generations in Japanese quail. A total of 4325 fresh eggs from 1326 females were collected each week during the egg-laying period to estimate heritability, genetic and phenotypic correlations, and correlated response of external and internal egg quality traits to selection for egg number (EN). The direct response to selection indicated an increase of $7.7 \pm 0.27$ eggs produced during the 90 days following production of the first egg. The correlated responses to selection indicated that selection for higher EN can be expected to increase EW and increase egg quality. Estimates of heritability ranged from 0.11 to 0.35 for external egg quality traits and from 0.08 to 0.32 for internal egg quality traits. Estimates of the genetic correlations of EN with external and internal traits were positive, ranging from 0.09 to 0.25 and from 0.02 to 0.27 , respectively. These estimates indicated few if any genetic antagonisms that would adversely affect selection response. However, eggshell thickness would not be expected to change as a result of selection for EN. Thus, the external and internal quality of Japanese quail eggs could be improved by selection for high egg production.
\end{abstract}

Keywords: correlated response, contrast, egg number, genetic correlations, heritability

"Corresponding author: Mahmoud.elatrouny@fagr.bu.edu.eg

\section{Introduction}

Japanese quail are fast-growing birds that are raised for egg and meat production in many countries (Lotfi et al., 2012). In European countries, producers focus on increasing meat production from Japanese quail, whereas in Asian countries, egg production is the most important area of interest for producers (Minvielle, 1998; Lotfi et al., 2012; El-Attrouny et al., 2020).

Japanese quail lay small eggs that may have three times the nutritive value of chicken eggs (Tunsaringkarn et al., 2013; Thomas et al., 2016). The increased demand for quail eggs, along with ongoing development in processing them, has necessitated an improvement in egg quality (Uluocak et al., 1995).

Egg quality measurements can be divided into external and internal (Song et al., 2000). External traits include egg weight (EW), eggshell thickness (EST), and shape index (ESI), which affect the hatchability and development of the chicks (Tserveni-Gousi, 1987; Khurshid et al., 2003). Egg shape index is the ratio of width to length and is an important criterion in determining egg quality. Round eggs and unusually long eggs do not look 'right', and do not fit well in egg cartons. These eggs are much more likely to be broken during shipment than those of normal shape, resulting in economic losses for breeders and traders (Uluocak, 1995; Fathi et al., 2016). Eggs that look abnormal are more likely to be rejected by the consumer, whereas defects in eggshell ultrastructure can result in breakage or impaired development of the embryo during incubation (Mills et al., 1994; Roberts, 2004; Duman et al., 2016).

Internal egg quality traits such as albumen index (Al) and yolk index (YI), percentage of albumen and yolk, and Haugh unit (HU) are important measures of egg freshness (Toussant \& Latshaw, 1999; Song et al., 2000; Silversides \& Scott, 2001). The $\mathrm{HU}$ and $\mathrm{YI}$ are used more frequently to determine internal egg quality than other measures. The height of the albumen surrounding the yolk is combined with egg weight and determines the $\mathrm{HU}$ score. Higher scores indicate better egg quality (Haugh, 1937; Kondaiah et al., 1983).

Egg production performance is usually assessed through traits such as egg numbers (EN) and EW during a defined period of production (Karabag et al., 2010; Durmus et al., 2017). Increased EN and EW 
have been the main aims of genetic improvement programmes in egg-laying Japanese quail (El-Attrouny \& Iraqi, 2020). Egg weight and shell weight (ESW) increase as with time after laying the first egg, whereas EST and hardness usually decrease (Lotfi et al., 2012).

Many selection programmes have sought to improve Japanese quail egg production, but these focused mostly on external egg traits (Minvielle, 1998; Cheng, 2002). Fathi et al. (2016) revealed that selection for higher EN and lower broken eggshell percentage improved ultrastructural features of the mammillary layer rather than selection for EST. Narinc et al. (2015) stated that specific gravity may be the selection criterion of choice for genetic improvement of eggshell quality. On the other hand, selection for higher egg numbers was predicted to reduce the thickness and strength of the eggshell (Lotfi et al., 2012).

For egg industries worldwide, eggs with good external and internal quality are critical to the economic viability of the industry, because egg quality is the most important factor in the price of table and hatching eggs (Roberts, 2004). Therefore, the objectives of the present study were threefold: i) to estimate the genetic and phenotypic correlation coefficients between egg numbers and external and internal egg quality traits; ii) to evaluate the effects of selection for high egg production on external and internal egg quality traits; and iii) to estimate the correlated response to selection for egg quality traits.

\section{Materials and Methods}

The protocol was approved by the institutional Animal Care and Use Committee of Benha University. A 5-generation selection experiment was conducted at the Poultry Research Farm, Faculty of Agriculture, Benha University, Egypt. There were 262 females in the base population that gave rise to 1064 additional females in the four subsequent selected generations. Each generation, birds were selected based on their estimated breeding value for the number of eggs produced during a 90 day period after laying the first egg.

Hatched chicks from each sire and dam were wing banded with small plastic bands, which were then replaced with wing metal bands at 14 days old. Chicks were raised in battery brooder cages from 1 to 14 days old and then transferred to rearing cages. Adult birds (one male with two females) were housed in stainless steel breeding cages with dimensions of $25 \times 25 \times 25 \mathrm{~cm}^{3}$ with a sloping floor for egg collection. A standard diet with $24 \%$ crude protein and $12.14 \mathrm{MJ} / \mathrm{kg}$ metabolizable energy was provided during the rearing period ( 0 - 6 weeks old). After 6 weeks, birds were provided with a standard layer mash diet (20\% crude protein and $12.56 \mathrm{MJ} / \mathrm{kg}$ metabolizable energy). Both diets were formulated to meet the nutrient requirements recommended for Japanese quail (NRC, 1994). The temperature of the henhouse was approximately $22{ }^{\circ} \mathrm{C}$. Feed and water were supplied ad libitum during the experimental period. Light was provided 24 hours a day for the first three weeks, and then a schedule with 16 hours of light and 8 hours of darkness was applied. The number of eggs laid by each female was recorded for the first 90 days of laying.

To evaluate egg quality traits, a total of 4325 fresh eggs were collected. Egg collection took place for three consecutive days each week during the first 90 days of the egg-laying period. The dam of each egg was identified according to its colouring pattern and the eggs were labelled to document parentage. Egg quality traits were recorded within 24 hours of collection. An electronic scale was used to weigh the egg to the nearest $0.1 \mathrm{~g}$. Egg length and width $(\mathrm{mm})$ were measured with an electronic digital calliper. External egg quality traits, including EW, ESI and ESW were determined for each egg after cracking it and cleaning residual albumen from the shell. Eggshell thickness was measured from the sharp, blunt and equatorial parts without a membrane with $0.01 \mathrm{~mm}$ sensitive electronic digital micrometres. Eggshell percentage (ESP) was calculated with this Aygun and Yetisir (2010) equation:

$$
\text { Eggshell percentage }(\%)=(E S W / E W) \times 100
$$

Internal egg quality traits were measured by gently breaking each egg with a scalpel and placing the contents on a flat surface. Internal egg quality traits - including albumen height (AH), albumen weight (AW), Al, albumen percentage $(\mathrm{AP})$, yolk height $(\mathrm{YH})$, yolk weight $(\mathrm{YW}), \mathrm{YI}$, and yolk percentage $(\mathrm{YP})$ - were recorded for each egg. The percentages of eggshell, albumen and yolk were expressed relative to EW. The heights of yolk and albumen were measured with a tripod micrometre, and the diameters of albumen and yolk were measured with an electronic digital calliper. Subsequently, the yolk was separated carefully from the albumen for weighing. Egg shape index, AI, YI and HU were calculated with these formulae (Haugh, 1937; Yannakopoulos \& Tserveni-Gousi, 1986; Altan et al., 1995; Altan et al., 1998):

$$
\begin{gathered}
\mathrm{ES}(\%)=\mathrm{AH} /[(\text { average albumen length }+ \text { width }) / 2] \times 100 \\
\mathrm{YI}(\%)=\mathrm{YH} / \text { yolk diameter } \times 100 \\
\mathrm{HU}=100 \log \left(\mathrm{AH}+7.57-1.7 \times \mathrm{EW}^{0.37}\right)
\end{gathered}
$$


Data of egg number and egg quality traits were analysed with this multi-trait animal model:

$$
y=X \beta+Z u+e
$$

Where: $y=$ the vector of observations,

$\beta=$ the vector of fixed generation effects with five levels,

$u=\mathrm{a}$ vector of random additive genetic effects for each bird in the pedigree,

$X$ and $Z$ = incidence matrices associating the observations with fixed and random effects, respectively, and

$e=$ a vector of random residual effects.

VCE6 software was used to calculate estimates of the variance components for random effects and heritability (Groeneveld et al., 2010). These estimates were used to solve the corresponding mixed model equations, and obtain solutions for the generation effects and their error variance-covariance matrix using PEST software (Groeneveld, 2006). Estimates of the contrasts between the five generations of selection were obtained with VCE6 software. Correlated response (CR) in trait y to selection (CSR) on trait $x$ was calculated with this equation from Falconer and Mackay (1996):

$$
C R_{y}=i_{x} h_{x} h_{y} r_{g} \sigma_{p y}
$$

Where: $i_{x}=$ selection intensity for trait $\mathrm{x}$,

$h_{x}$ and $h_{y}=$ square root of heritability for traits $\mathrm{x}$ and $\mathrm{y}$, respectively,

$r_{g}=$ genetic correlation of traits $\mathrm{x}$ and $\mathrm{y}$, and

$\sigma_{p y}=$ phenotypic standard deviation of trait $\mathrm{y}$.

\section{Results and Discussion}

Descriptive statistics for the external and internal egg quality traits are presented in Table 1 . These findings are within the ranges for Japanese quail reported by Taha (2009), who found EN ranged from 51.97 to 72.83 , and Fathi et al. (2016), who observed average ENs of 57.0 and 65.8 eggs in the control and selected lines, respectively.

Table 1 Descriptive statistics for external and internal egg quality traits in Japanese quail

\begin{tabular}{lrrrrr}
\hline Trait & Mean & SD & CV,\% & Minimum & Maximum \\
\hline Egg number & 63.20 & 6.14 & 9.71 & 53.00 & 70.00 \\
External egg quality traits & & & & & \\
$\quad$ Egg weight, g & 13.63 & 1.32 & 9.68 & 10.06 & 16.70 \\
Egg shape index, \% & 78.72 & 3.25 & 4.12 & 61.90 & 87.88 \\
Shell thickness, mm & 0.23 & 0.02 & 8.69 & 0.19 & 0.29 \\
Shell weight, g & 1.25 & 0.23 & 11.05 & 0.78 & 1.47 \\
Shell percentage, \% & 13.91 & 1.71 & 12.29 & 8.32 & 16.47 \\
Internal egg quality traits & & & & & \\
Albumen height, mm & 4.13 & 0.17 & 4.11 & 2.56 & 6.74 \\
Albumen weight, g & 7.33 & 1.19 & 16.23 & 4.99 & 10.39 \\
Albumen index, \% & 10.36 & 2.05 & 19.78 & 5.63 & 16.52 \\
Albumen percentage, \% & 53.78 & 4.68 & 8.70 & 30.37 & 68.52 \\
Yolk height, mm & 9.78 & 1.45 & 14.82 & 6.57 & 12.74 \\
Yolk weight, g & 4.40 & 0.19 & 4.31 & 2.94 & 6.14 \\
Yolk index, \% & 48.63 & 6.74 & 13.85 & 31.52 & 62.53 \\
Yolk percentage, \% & 32.27 & 5.13 & 15.89 & 23.41 & 43.15 \\
Haugh unit & 88.24 & 10.65 & 12.06 & 79.52 & 94.53 \\
\hline
\end{tabular}

CV: Coefficient of variation 
The present study revealed that the average EW was $13.63 \mathrm{~g}$. Khaldari et al. (2010) and Copur et al. (2010) reported similar averages of $13.40 \mathrm{~g}$ and $13.25 \mathrm{~g}$. In contrast, lower EW with a range of $10.27-12.76$ $\mathrm{g}$ was reported for quails by Hassan et al. (2003), Kul and Seker (2004), Sari et al. (2016), Al-Daraji et al. (2010), and Narinc et al. (2015). Alkan et al. (2010) recorded a higher EW with an average of $14.14 \mathrm{~g}$ in a high bodyweight line of Japanese quail.

Egg shape index is important for good hatchability and consumer preferences in table eggs. In the current study, the average value of ESI was high (78.72\%), which might be because of the genetic selection programme. The current value is within the ESI range values of $76.29 \%$ and $80.45 \%$ that were reported in the literature (Sezer, 2007; Alkan et al., 2010; Nowaczewski et al., 2010; Daikwo et al., 2013; Narinc et al., 2015). In contrast, Kul and Seker (2004) reported an ESI value of $74.90 \%$.

Average values for eggshell thickness, ESW and ESP (Table 1) were similar to those reported by Kul and Seker (2004) and Yilmaz et al. (2011), who found an average EST of $0.23 \mathrm{~mm}$. Nasr et al. (2016) reported a value of $1.31 \mathrm{~g}$ for ESW. However, values lower than those observed in the current study were reported by Lotfi et al. (2012), El-Tarabany et al. (2015), and Sari et al. (2016). Also, Narinc et al. (2015) reported averages of $1.04 \mathrm{~g}$ and $8.17 \%$ for ESW and ESP.

Average values for internal egg quality traits (Table 1) were also within the ranges reported in the literature for $\mathrm{AH}(3.80 \mathrm{~mm}$ and $4.58 \mathrm{~mm})$, AW (6.68 g and $7.04 \mathrm{~g}), \mathrm{Al}(9.37 \%$ to $10.67 \%)$, and AP (54.45\% and 59.83\%) (Nazligül et al., 2001; Kul \& Seker, 2004; Lotfi et al., 2012; El-Tarabany et al., 2015). The average values of $\mathrm{YH}, \mathrm{YW}, \mathrm{YI}$, and $\mathrm{YP}$ also were within the range of value that were previously reported: $\mathrm{YH}$ (9.90 $\mathrm{mm}$ to $10.84 \mathrm{~mm}$ ), YW (3.60 g to $4.83 \mathrm{~g}$ ), YI (42.06 to 50.0), and YP (32.57\% to $41.53 \%$ ) (Alkan et al., 2010, Lotfi et al., 2012; Sari et al., 2016; Nasr et al., 2016). Altan et al. (1998) reported that egg shape index and its component traits, and $\mathrm{YH}$ and $\mathrm{YW}$ increased in a line of Japanese quail selected for increased body weight compared to a random-bred control line.

The average value of $\mathrm{HU}$ in the present study was consistent with Alkan et al. (2010), in which HU values between 86.07 and 88.28 were observed. Nowaczewski et al. (2010) and Zita et al. (2013) presented a similar $\mathrm{HU}$ values. However, the average value of $\mathrm{HU}$ in the current study was higher than the range of observations reported by Kul and Seker (2004), Daikwo et al. (2013), and Nowaczewski et al. (2010), and lower than those of El-Tarabany et al. (2015) and Sari et al. (2016), respectively.

The heritability estimates of for egg number and thee external egg quality traits ranged from low to moderate (Table 2). In agreement with the current findings, Daikwo et al. (2013) reported an estimated heritability of 0.37 for EW. However, MacNeil et al. (1984) and Stivanin et al. (2019) reported lower estimates of heritability ( 0.16 and 0.11 , respectively) for EW in Japanese quail. In contrast, Sezer (2007) and Lotfi et al. (2015) estimated the heritability for $\mathrm{EW}$ in Japanese quail to be 0.83 and 0.41 , respectively. The heritability of ESI observed in this study was lower than the estimates of 0.51 and 0.38 reported by Sezer (2007) and Narinc et al. (2015), respectively, whereas, Lotfi et al. (2012) estimated a slightly lower heritability of 0.14 for ESI in quail eggs. The heritability estimates obtained in the present study were numerically higher than the estimates for EST, ESW, and ESP of $0.13,0.15$ and 0.09 , respectively, from Lotfi et al. (2012). In the current study, estimates of heritability for ESW were lower than those in previous reports (Sato et al., 1989; Minvielle, 1998; Narinc et al., 2015) wherein the values ranged from 0.60 to 0.84 . Moderate heritability estimates for ESP (0.31) was reported by Sezer (2007). The relatively low estimates heritability might be attributable to variation in environmental factors such as nutrition, husbandry and temperature that were not fully accounted for analysing the data and thus inflating the non-genetic variance (Sari et al., 2016).

Estimates of the contrasts between the selected generations and base population, and heritabilities of the traits are presented in Table 2. The contrast among estimates of these generations was significant for EN (7.7 eggs), indicating direct response to selection. Similarly, Alkan et al. (2013) and Mahmoud et al. (2016) reported positive direct responses to selection in Japanese quail.

The contrasts, indicative of correlated responses to selection, were significant for all external egg quality traits between generations, except EST. The estimated genetic correlations of these traits with EN (Table 3) support the observed correlated responses. Altan et al. (1998) and Alkan et al. (2010) also detected no significant correlated response in EST between the control and the selected groups of Japanese quail. The increase in ESW may be attributed to the increase in EW through generations (Karaman \& Bascillar, 2012). Altan et al. (1998) found ESW to be increased due to selection for higher body weight compared with a control population. Thus, the present results and some observations in the literature support the conclusion that external quality traits can be improved through selection for higher EN. However, Lotfi et al. (2012) reported estimates of the genetic correlations of EN with EW, AW and YW as being negative $-0.56,-0.44$, and -0.41 , respectively, and MacNeil et al. (1984) found the genetic correlation of EN and $\mathrm{EW}$ to be not different from zero. 
Table 2 Contrasts indicating direct and correlated response in external egg quality traits to selection for increased egg number, and the associated estimates of heritability, for Japanese quail

\begin{tabular}{lcc}
\hline Traits & Contrast & $\mathrm{h}^{2} \pm \mathrm{SE}$ \\
\hline Egg number & $7.7 \pm 0.27^{*}$ & $0.26 \pm 0.05$ \\
External egg quality traits & & \\
Egg weight, g & $1.12 \pm 0.24^{\star}$ & $0.35 \pm 0.07$ \\
Egg shape index, \% & $1.48 \pm 0.21^{*}$ & $0.21 \pm 0.08$ \\
Shell thickness, mm & $0.04 \pm 0.01$ & $0.19 \pm 0.03$ \\
Shell weight, g & $0.61 \pm 0.23^{\star}$ & $0.28 \pm 0.11$ \\
Shell percentage, \% & $1.52 \pm 0.33^{*}$ & $0.11 \pm 0.03$ \\
\hline
\end{tabular}

Table 3 Genetic (above the diagonal), and phenotypic (below the diagonal) correlations for external egg traits and egg number in Japanese quail

\begin{tabular}{lcccccc}
\hline Traits & Egg number & Egg weight & Shape index & $\begin{array}{c}\text { Shell } \\
\text { thickness }\end{array}$ & Shell weight & $\begin{array}{c}\text { Shell } \\
\text { percentage }\end{array}$ \\
\hline Egg number & & $0.25 \pm 0.05$ & $0.19 \pm 0.01$ & $0.09 \pm 0.01$ & $0.12 \pm 0.02$ & $0.15 \pm 0.02$ \\
Egg weight & $0.34 \pm 0.90$ & & $0.31 \pm 0.12$ & $0.16 \pm 0.02$ & $0.27 \pm 0.03$ & $0.23 \pm 0.06$ \\
Shape index & $0.16 \pm 0.02$ & $0.18 \pm 0.03$ & & $0.11 \pm 0.01$ & $0.05 \pm 0.01$ & $-0.11 \pm 0.07$ \\
Shell thickness & $0.13 \pm 0.03$ & $0.19 \pm 0.03$ & $0.22 \pm 0.12$ & & $0.21 \pm 0.06$ & $0.13 \pm 0.04$ \\
Shell weight & $0.07 \pm 0.02$ & $0.21 \pm 0.02$ & $0.10 \pm 0.04$ & $0.41 \pm 0.07$ & & $0.03 \pm 0.01$ \\
Shell percentage & $0.17 \pm 0.03$ & $0.16 \pm 0.04$ & $0.16 \pm 0.06$ & $0.28 \pm 0.05$ & $0.24 \pm 0.09$ & \\
\hline
\end{tabular}

Genetic correlations among the external egg traits were positive and low or moderate (Table 3). Sari et al. (2016) showed a negative genetic correlation (-0.06) between EW and ESI. However, they revealed a high and positive genetic correlation between EW and ESW (0.85). A similar result was reported by Narinc et al. (2015), who found that the genetic correlation between EW and ESW was 0.75 . While ESI increased by $1.48 \%$ as a correlated response to selection, is not regarded as a good indicator of EST, ESW and shell ratio due to the low genetic correlations. A negative estimate of the genetic correlation of EW with EST $(-0.16)$ was reported by Daikwo et al. (2013).

Phenotypic correlations of EN with external quality traits were positive and ranged from 0.07 to 0.34 (Table 3). Thus, the phenotypic correlations between EN and external quality traits were similar to the genetic correlations. The current results are in contrast to those of Kul and Seker (2004), who found significant phenotypic correlations of EW with ESI (-0.22), EST (0.21), ESW (0.60), and ESP (-0.22). Daikwo et al. (2013) reported positive estimates of the phenotypic correlations of EW with ESI (0.54) and EST (0.05). Özçelik (2002) explained that eggshell quality and ESP depend on egg size and egg weight, and that there is a high correlation between shell strength and shell thickness. There might also be an applied benefit to be derived from ESI in determining eggshell strength (Yannakopoulos \& Tserveni-Gousi, 1986).

The heritability estimates of internal egg quality traits generally were low and moderate (Table 4). Heritability of internal egg quality traits was similar to the values reported by Sari et al. (2016) and Lotfi et al. (2012) were between 0.02 and 0.34 . Daikwo et al. (2013) reported estimates of heritability for $\mathrm{AH}, \mathrm{HU}$ and $\mathrm{YH}$ traits in Japanese quail of $0.27,0.30$ and 0.11 , respectively. In the present study, heritability estimate of AW was similar to the estimate (0.29) reported by Lotfi et al. (2012) and lower than (0.42) that reported by Singh et al. (2011). Singh et al. (2011) and Lotfi et al. (2012) reported that heritability estimates of YW of 0.32 and 0.33 , respectively. The estimate of heritability for $\mathrm{HU}$ in this study was lower than the estimate (0.40) reported by Daikwo et al. (2013). 
Table 4 Contrasts indicating correlated response in internal egg quality traits to selection for increased egg number, and the associated estimates of heritability, for Japanese quail

\begin{tabular}{lll}
\hline Internal egg quality traits & Contrast & $h^{2} \pm S E$ \\
\hline Albumen height, mm & $0.21 \pm 0.03^{*}$ & $0.24 \pm 0.06$ \\
Albumen weight, g & $0.88 \pm 0.27^{*}$ & $0.32 \pm 0.19$ \\
Albumen index, \% & $0.34 \pm 0.16^{*}$ & $0.09 \pm 0.01$ \\
Albumen percentage, \% & $2.58 \pm 0.30^{*}$ & $0.08 \pm 0.02$ \\
Yolk height, mm & $0.17 \pm 0.04^{*}$ & $0.18 \pm 0.04$ \\
Yolk weight, g & $0.72 \pm 0.19^{*}$ & $0.27 \pm 0.06$ \\
Yolk index, \% & $2.02 \pm 0.18^{*}$ & $0.09 \pm 0.01$ \\
Yolk percentage, \% & $3.20 \pm 1.23^{*}$ & $0.20 \pm 0.11$ \\
Haugh unit & $2.14 \pm 0.14^{*}$ & $0.21 \pm 0.10$
\end{tabular}

${ }^{*}$ Contrast was significantly different from 0 at $\alpha=0.05$

Selection for EN improved all of the internal egg quality traits. This reflects a positive correlated response in internal egg quality traits because of the selection for higher egg numbers based on the breeding value. However, support for this conclusion is tenuous because the estimated genetic correlations of EN with $\mathrm{YH}, \mathrm{AP}, \mathrm{Al}, \mathrm{AW}$ and $\mathrm{YI}$ are quite low (Table 5).

Haugh unit is an important criterion for evaluating internal egg quality. Sari et al. (2016) found genetic correlations of yolk diameter and $\mathrm{YW}, \mathrm{AH}$ and $\mathrm{HU}$, and $\mathrm{AW}$ and $\mathrm{AP}$ that were large and positive. In the present study, $\mathrm{HU}$ and $\mathrm{AH}$ had a particularly high genetic correlation. There were also moderate genetic correlations of $\mathrm{AH}$ and $\mathrm{AW}$ and $\mathrm{HU}$ and $\mathrm{AW}$. All these genetic correlations can be used in multiple trait selection to improve the egg quality. Controlling for the age of the bird would be an important part of this process because the albumen quality of the freshly laid egg decreases with advancing age (Smile et al., 2005).

Phenotypic correlations between EN and internal egg quality traits were also positive, but in general low $(<0.3)$ and several were negative (Table 6). Kul and Seker (2004) and Özçelik (2002) reported that an increase in EW would result in a decrease in YP. Kul and Seker (2004) observed that YP and ESP had negative phenotypic correlations with AP. El-Tarabany et al. (2015) reported that EST was positively correlated with $\mathrm{YH}(0.31), \mathrm{AH}(0.26), \mathrm{YI}(0.20)$, and $\mathrm{HU}(0.29)$. Components of the albumen and yolk change phenotypically during storage and these changes affect egg quality negatively. Among the factors affecting egg quality during storage are temperature and relative humidity which have a direct relationship with egg deterioration, besides the duration of storage (Williams, 1992; Silversides \& Scott, 2001).

The predicted correlated responses to selection for increased egg number also indicated significant favourable changes in both the external and internal egg quality traits, with the exception of EST (Table 5). These predictions provide a second estimate of the contrast between the base population and the final selected generation and are more precise as indicated by their smaller standard errors relative to the contrasts of generations. Thus, selection for higher egg numbers may lead to an increase in EW and better external and internal egg quality with little or no change in EST. Alkan et al. (2010) showed that selection for high bodyweight, resulted in an increase EW, YH, AH, and ESW, whereas EST and HU did not change. Nasr et al. (2016) found that a high bodyweight line of selected quail laid significantly heavier eggs with higher eggshell weight and shell thickness when compared with a line selected for low bodyweight and a randombred control line. 
Table 5 Genetic (above the diagonal), and phenotypic (below the diagonal) correlations for internal egg quality traits and number of eggs produced by Japanese quail

\begin{tabular}{|c|c|c|c|c|c|c|c|c|c|c|}
\hline Trait & EN & $\mathrm{AH}$ & AW & $\mathrm{Al}$ & AP & $\mathrm{YH}$ & YW & $\mathrm{YI}$ & YP & $\mathrm{HU}$ \\
\hline EN & & $0.22 \pm 0.07$ & $0.02 \pm 0.01$ & $0.07 \pm 0.01$ & $0.11 \pm 0.07$ & $-0.05 \pm 0.02$ & $0.20 \pm 0.02$ & $0.06 \pm 0.02$ & $0.16 \pm 0.06$ & $0.27 \pm 0.05$ \\
\hline $\mathrm{AH}$ & $0.11 \pm 0.06$ & & $0.30 \pm 0.04$ & $0.23 \pm 0.03$ & $0.08 \pm 0.01$ & $-0.07 \pm 0.02$ & $-0.16 \pm 0.03$ & $-0.17 \pm 0.04$ & $0.20 \pm 0.05$ & $0.58 \pm 0.04$ \\
\hline AW & $0.13 \pm 0.05$ & $0.16 \pm 0.07$ & & $0.27 \pm 0.04$ & $0.33 \pm 0.08$ & $0.11 \pm 0.04$ & $0.11 \pm 0.06$ & $0.07 \pm 0.02$ & $0.11 \pm 0.05$ & $0.18 \pm 0.06$ \\
\hline $\mathrm{Al}$ & $0.17 \pm 0.03$ & $0.14 \pm 0.07$ & $0.28 \pm 0.10$ & & $0.12 \pm 0.06$ & $0.05 \pm 0.01$ & $0.09 \pm 0.03$ & $0.13 \pm 0.02$ & $0.04 \pm 0.01$ & $0.14 \pm 0.05$ \\
\hline AP & $0.09 \pm 0.02$ & $-0.21 \pm 0.08$ & $0.32 \pm 0.08$ & $0.18 \pm 0.04$ & & $-0.19 \pm 0.04$ & $0.09 \pm 0.02$ & $0.13 \pm 0.03$ & $0.12 \pm 0.03$ & $0.10 \pm 0.05$ \\
\hline $\mathrm{YH}$ & $-0.19 \pm 0.07$ & $0.08 \pm 0.02$ & $-0.14 \pm 0.01$ & $0.09 \pm 0.03$ & $0.06 \pm 0.01$ & & $0.19 \pm 0.03$ & $0.25 \pm 0.06$ & $0.12 \pm 0.03$ & $0.04 \pm 0.01$ \\
\hline YW & $0.08 \pm 0.02$ & $0.14 \pm 0.04$ & $0.18 \pm 0.05$ & $0.29 \pm 0.06$ & $-0.07 \pm 0.02$ & $0.16 \pm 0.02$ & & $0.31 \pm 0.05$ & $0.29 \pm 0.04$ & $0.07 \pm 0.03$ \\
\hline $\mathrm{YI}$ & $-0.15 \pm 0.04$ & $0.09 \pm 0.05$ & $0.05 \pm 0.01$ & $0.04 \pm 0.01$ & $-0.13 \pm 0.03$ & $0.27 \pm 0.07$ & $0.21 \pm 0.07$ & & $0.20 \pm 0.07$ & $0.09 \pm 0.03$ \\
\hline YP & $-0.10 \pm 0.03$ & $0.18 \pm 0.03$ & $0.09 \pm 0.02$ & $-0.19 \pm 0.05$ & $0.02 \pm 0.05$ & $0.23 \pm 0.08$ & $0.22 \pm 0.08$ & $0.18 \pm 0.05$ & & $0.06 \pm 0.04$ \\
\hline $\mathrm{HU}$ & $0.12 \pm 0.01$ & $0.24 \pm 0.03$ & $0.12 \pm 0.07$ & $0.11 \pm 0.04$ & $0.19 \pm 0.05$ & $0.14 \pm 0.01$ & $0.05 \pm 0.01$ & $0.07 \pm 0.03$ & $0.12 \pm 0.07$ & \\
\hline
\end{tabular}

EN: egg number, AH: albumen height, AW: albumen width, Al: albumen index, AP: albumen percentage, YH: yolk height, YW: yolk width, Yl: yolk index, YP: yolk percentage, HU: Haugh unit 
Table 6 Estimates of correlated response to selection for increased egg number in traits that received no direct selection pressure through four generations of selection

\begin{tabular}{lc}
\hline External egg quality traits & Correlated response \\
\hline Egg weight, g & $1.22 \pm 0.03^{\star}$ \\
Egg shape index \% & $1.01 \pm 0.06^{\star}$ \\
Eggshell thickness mm & $0.02 \pm 0.02$ \\
Eggshell weight g & $0.42 \pm 0.02^{\star}$ \\
Eggshell percentage \% & $1.08 \pm 0.04^{\star}$ \\
Internal egg quality traits & \\
Albumen height, mm & $0.40 \pm 0.02^{\star}$ \\
Albumen weight, g & $0.79 \pm 0.04^{\star}$ \\
Albumen index, \% & $0.75 \pm 0.03^{\star}$ \\
Albumen percentage, \% & $0.51 \pm 0.05^{\star}$ \\
Yolk height, mm & $0.62 \pm 0.01^{\star}$ \\
Yolk weight, g & $0.49 \pm 0.03^{\star}$ \\
Yolk index, \% & $1.05 \pm 0.04^{\star}$ \\
Yolk percentage, \% & $1.58 \pm 0.05^{\star}$ \\
Haugh unit & $2.32 \pm 0.02^{\star}$ \\
\hline${ }^{*} P<0.05$ & \\
\hline
\end{tabular}

\section{Conclusion}

The relationship between egg quality and quantity is a major issue from the breeders' point of view. This research indicates that selection for higher EN can be effective and also increase EW and egg quality. Increasing $\mathrm{HU}$ also indicates firmer and stronger albumen with high density to support embryo development and successful hatching. All of this would be reflected in enhanced economic viability of the egg industry.

\section{Acknowledgments}

The authors thank the personnel working at the Poultry Research Farm at Faculty of Agriculture, Benha University, Egypt.

\section{Authors' Contributions}

MME and MMI designed the research project. MME performed the experiment and collected data. MME and MMI analysed the data and interpreted the results. MME wrote the initial manuscript. The authors jointly revised and finalised the manuscript for publication.

\section{Conflict of Interest Declaration}

The authors declare that they have no conflicting interests.

\section{References}

Al-Daraji, H.J., Razuki, W.M., Al-Hayani, W.K. \& Al-Hassani, A.S., 2010. Effect of dietary linseed on egg quality of laying quail. Int. J. Poult. Sci. 9, 584-590. DOI: 10.3923/ijps.2010.584.590

Alkan, S., Karabag, K., Galic, A., Karsli, T. \& Balcioglu, M.S., 2010. Effects of selection for body weight and egg production on egg quality traits in Japanese quails (Coturnix coturnix japonica) of different lines and relationships between these traits. Kafkas Univ. Vet. Fak. Derg. 16, 239-244.

Alkan, S., Karsli, T., Karabag, K. \& Galic, A., 2013. The effects of selection and season on clutch traits and egg production in Japanese quails (Coturnix coturnix japonica) of different lines. SDU Journal of the Faculty of Agriculture/SDÜ Ziraat Fakültesi Dergisi, 8(1).

Altan, Ö., Ismail, O.Ğ.U.Z. \& Akbas, Y., 1998. Effects of selection for high body weight and age of hen on egg characteristics in Japanese quail (Coturnix coturnix japonica). Turk J. Vet. Anim. Sci. 22, 467-474.

Altan, O., Oguz, I. \& Settar, P., 1995. Effects of hatchability traits of egg weight and specific gravity in Japanese quail. Turk J. Agric. 19, 219 -222. 
Aygun, A. \& Yetisir, R., 2010. The relationships among egg quality characteristic of different hybrid layers to forced molting programs with and without feed withdrawal. Journal of Animal and Veterinary Advances 9, 710-715. http://dx.doi.org/10.3923/javaa.2010.710.715

Cheng, K.M., 2002. Japanese quail breeding: Where are we heading? Proceedings of the 1st Simpósio International de Coturnicultura, CD-Rom, Universidade Federal de Lavras, Brazil.

Copur, G., Baylan, M. \& Canogullarl, S., 2010. Egg weight but not egg shape index, determines the hatchability in Japanese quail (Coturnix coturnix japonica). J. Anim. Vet. Adv. 9, 1890-1895. http://www.medwelljournals.com/fulltext/?doi=javaa.2010.1890.1895

Daikwo, S.I., Momoh, O.M. \& Dim, N.I., 2013. Heritability estimates of genetic and phenotypic correlations among some selected carcass traits of Japanese quail (Coturnix coturnix japonica) raised in a subhumid climate. J. Bio. Agric. \& Health 3, 60-65. http://www.iiste.org/Journals/index.php/JBAH/article/view/5370/5349

Duman, M., Sekeroglu, A., Yildirim, A., Eleroglu, H. \& Camci, O., 2016. Relation between egg shape index and egg quality characteristics. Euro. Poult. Sci. 80: 1-9.

Durmus, I., Alkan, S., Narinc, D., Karabag, K. \& Karsli, T., 2017. Effects of mass selection on egg production on some reproductive traits in Japanese quail. Euro. Poult. Sci. 1, 81. DOI: 10.1399/eps.2017.168

El-Attrouny, M.M. \& Iraqi, M.M. 2020. Correlated responses to short-term selection for egg production traits in Japanese quail. Asian J. Poult. Sci, 14, 24-31. https://dx.doi.org/10.3923/ajpsaj.2020.24.31

El-Attrouny, M.M., Manaa, E.A. \& Ramadan, S.I., 2020. Genetic evaluation and selection correlated response of growth traits in Japanese quail. South African Journal of Animal Science 50, $325-333$. http://dx.doi.org/10.4314/sajas.v50i2.16

El-Tarabany, M.S., Abdel-Hamid, T.M. \& Mohammed, H.H., 2015. Effects of cage stocking density on egg quality traits in Japanese quails. Kafkas Univ. Vet. Fak. Derg. 21, 13 -18. DOI: 10.9775/kvfd.2014.11374

Falconer, D.S. \& Mackay, F.C., 1996. Introduction to quantitative genetics. Fourth edition. Longman, Harlow, Essex, England. Pp.108-183.

Fathi, M.M., El-Dlebshany, A.E., El-Deen, M.B., Radwan, L.M. \& Rayan, G.N., 2016. Effect of long-term selection for egg production on eggshell quality of Japanese quail (Coturnix coturnix japonica). Poult. Sci. 95, 2570-2575. https://doi.org/10.3382/ps/pew233

Groeneveld, E., 2006. PEST user's manual. Institute of Animal Husbandry and Animal Behaviour, FAL, Germany.

Groeneveld, E., Kovac, M. \& Mielenz, N., 2010. VCE - user's guide and reference manual, version 6.0. Institute of Farm Animal Genetics, Neustadt, Germany.

Hassan, S.M., Mady, M.E., Cartwright, A.L., Sabri, H.M. \& Mobarak, M.S., 2003. Effect of early feed restriction on reproductive performance in Japanese quail (Coturnix coturnix japonica). Poult. Sci. 82,1163-1169. https://doi.org/10.1093/ps/82.7.1163

Haugh, R.R., 1937. The Haugh unit for measuring egg quality. United States Egg and Poultry Magazine 43, $522-555$.

Karabag, K., Alkan, S. \& Balcloglu, M.S., 2010. The differences in some production and clutch traits in divergently selected Japanese quails. Kafkas Univ. Vet. Fak. Derg. 16, 383-387. DOI:10.9775/kvfd.2009.826

Karaman, K. \& Bascillar, M.S., 2012. Investigation of Japanese quail progenies in terms of egg yield and quality levels grown at six different management conditions in Turkey. International Conference on Environmental and Biological Sciences, 21-22 December 2012, Bangkok, Thailand. Pp. 32-34.

Khaldari, M., Pakdel, A., Mehrabani Yegane, H., Nejati Javaremi, A. \& Berg, P., 2010. Response to selection and genetic parameters of body and carcass weights in Japanese quail selected for 4 -week body weight. Poult. Sci. 89, 18341841. DOI: $10.3382 / p s .2010-00725$

Khurshid, A.M., Froog, F.R., Durrani, K. \& Sarbiland, N. Chand., 2003. Predicting egg weight, shell weight, shell thickness and hatching weight of Japanese quail using various egg traits as regressors. Int. J. Poult. Sci. 2, 164167. DOI: 10.3923/ijps.2003.164.167

Kondaiah, N., Panda, B. \& Singhal, R.A., 1983. Internal egg-quality measure for quail eggs. Indian J. Anim. Sci. 53, $1261-1264$

Kul, S. \& Seker, I., 2004. Phenotypic correlations between some external and internal egg quality traits in the Japanese quail (Coturnix coturnix japonica). Int. J. Poult. Sci. 3, 400-405. DOI: 10.3923/ijps.2004.400.405

Kumari, P.B., Gupta, R.B., Prakash, G.M. \& Reddy, R.A., 2008. A study of egg quality traits in Japanese quails. Journal of Veterinary and Animal Sciences 4, 227-231

Lotfi, E., Zerehdaran, S. \& Raoufi, Z., 2012. Genetic properties of egg quality traits and their correlations with performance traits in Japanese quail. Br. Poult. Sci. 53, 585-591. https://doi.org/10.1080/00071668.2012.723197

MacNeil, M.D., Kress, D.D., Flower, A.E. \& Blackwell, R.L., 1984. Effects of mating system in Japanese quail 2. Genetic parameters, response and correlated response to selection Theor. Appl. Genet. 67, 407-412. https://doi.org/10.1007/bf00263402

Mahmoud, B.Y.F., Abou Khadiga, G. \& El-Full, E.A., 2016. Correlated response to selection for some egg performance traits in egg line of Japanese quail. Animal Production Science 56, 913-917. https://doi.org/10.1071/AN14114

Mills, A.D., Herron, K.M., Bain, M.M., Solomon, S.E. \& Faure, J., 1994. Eggshell quality in Japanese quail (Coturnix coturnix japonica) genetically selected for high or low levels of fearfulness. Proceedings of the 9th European Poultry Conference, Glasgow, UK. Pp. 292-293

Minvielle, F., 1998. Genetic and breeding of Japanese quail for production around the world. Proceedings 6th Asian Pacific Poultry Congress, Nagoya, Japan. https://hal.inrae.fr/hal-02764843

Narinc, D., Aygun, A., Karaman, E. \& Aksoy, T., 2015. Eggshell quality in Japanese quail: Characteristics, heritabilities and genetic and phenotypic relationships. Animal 9,1091-1096. https://doi.org/10.1017/S1751731115000506 
Nasr, M.A., El-Tarabany, M.S. \& Toscano, M.J., 2016. Effects of divergent selection for growth on egg quality traits in Japanese quail. Anim. Prod. Sci. 56, 1797-1802. https://doi.org/10.1071/AN14911

Nazligül, A., Türkyilmaz, K. \& Bardakcioğlu, H.E., 2001. A study on some production traits and egg quality characteristics of Japanese quail. Turk J. Vet. Anim. Sci. 25, 1007-1013.

Nowaczewski, S., Kontecka, H., osiński, A., Koberling,R. S. \& Koronowski, P., 2010. Egg quality of Japanese quail depends on layer age and storage time. Folia Biologica 58, 201-207. DOI: 10.3409/fb58_3-4.201-207

NRC, 1994. Nutrient requirements of poultry. Ninth revised edition. National Research Council, National Academies Press. Washington DC. http://www.book.nap.edu/catalog/2114.htm

Özçelik, M., 2002. The phenotypic correlations among some external and internal quality characteristics in Japanese quail eggs. Veterinary Journal of Ankara University, Turkey.

Panda, B. \& Singh, R.P., 1990. Developments in processing quail meat and eggs. World's Poult. Sci. J. 46, $219-234$. https://doi.org/10.1079/WPS19900022

Roberts, J.R., 2004. Factors affecting egg internal quality and eggshell quality in laying hens. J. Poult. Sci. 41, $161-177$. https://doi.org/10.2141/jpsa.41.161

Saatci, M., Omed, H. \& Ap Dewi, I., 2006. Genetic parameters from univariate and bivariate analyses of egg and weight traits in Japanese quail. Poult. Sci. 85, 185-190. https://doi.org/10.1093/ps/85.2.185

Sari, M., Tilki, M. \& Saatci, M., 2016. Genetic parameters of egg quality traits in long-term pedigree recorded Japanese quail. Poult. Sci. 95, 1743-1749. http://dx.doi.org/10.3382/ps/pew118

Sato, K., Ida, N. \& Ino, T., 1989. Genetic parameters of egg characteristics in Japanese quail. Experimental Animals 38, 55-59. https://doi.org/10.1538/expanim1978.38.1_55

Sezer, M., 2007. Heritability of exterior egg quality traits in Japanese quail. J. Appl. Bio. Sci. 1, 37-40.

Sezer, M., 2008. Heritability of Interior egg quality traits for Japanese quail. Int. J. Nat. Engr. Sci. 2: 77-79.

Silversides, F.G. \& Scott, A.T., 2001. Effect of storage and layer age on quality of eggs from two lines of hens. Poult. Sci. 80, 1240-1245. https://doi.org/10.1093/ps/80.8.1240

Singh, C.B., Singh, C.V., Kumar, D. \& Jilani, M.H., 2011. Genetic parameters of egg quality traits in Japanese quails (Coturnix coturnix japonica). Pantnagar Journal of Research 9, 259-261.

Solomon, S.E. 1991. Egg and eggshell quality, Wolf, London.

Song, K.T., Choi, S.H. \& Oh, H.R., 2000. A comparison of egg quality of pheasant, chukar, quail and guinea fowl. Asian. Austral. J. Anim, 13, 986-990. DOI:10.5713/ajas.2000.986

Stivanin, T.E., Maia, F.C., Migliorini, E., Kluska, S., Amorim, T., Lovatto, F.S. \& Martins, E.N., 2019. Evaluation of selection criteria in laying quail (Coturnix coturnix japonica). Livest. Res. Rural Dev. $31,9$. https://lrrd.cipav.org.co/Irrd31/9/cont3109.htm

Taha, A.E., 2009. Laying performance of Japanese young chickens in response to chromic heat stress quails divergently selected for body weight under conditions. Egypt. J. Anim. Prod, 32, 237-251.

Thomas, K.S., Jagatheesan, P.R., Reetha, T.L. \& Rajendran, D., 2016. Nutrient composition of Japanese quail eggs. Inter. J. Sci. Enviro. and Tech. 5,1293-1295.

Toussant, M.J. \& Latshaw, J.D., 1999. Ovomucin content and composition in chicken eggs with different interior. J. Sci. Food. Agric. 79, 1666-1670.

Tserveni-Gousi, A.S., 1987. Relationship between parental age, egg weight and hatching weight of Japanese quail. Br. Poult. Sci. 28, 749-752. http://dx.doi.org/10.1080/00071668708417012

Tunsaringkarn, T., Tungjaroenchai, W. \& Siriwong, W., 2013. Nutrient benefits of Quail (Coturnix coturnix japonica) eggs. International Journal of Scientific and Research publications; 3(5).

Uluocak, A.N., Okan, F., Efe, E. \& Nacar, H., 1995. Exterior and interior quality of characteristics of eggs and their variation according to age in Japanese quail. Turk J. Vet. Anim. Sci, 19: 181- 185.

Williams, K.C., 1992. Some factors affecting albumen quality with particular reference to Haugh unit score. World's Poult. Sci. J. 48, 5-16. https://doi.org/10.1079/WPS19920002

Yannakopoulos, A.L. \& Tserveni-Gousi, A.S., 1986. Quality characteristics of quail eggs. Br. Poult. Sci. 27, $171-176$. https://doi.org/10.1080/00071668608416870

Yilmaz, A., Tepeli, C. \& Caglayan, T., 2011. External and internal egg quality characteristics in Japanese quails of different plumage color lines. J. Food Agric. Environ. 9, 375-379.

Zita, L., Ledvinka, Z. \& Klesalová, L.., 2013. The effect of the age of Japanese quails on certain egg quality traits and their relationships. Veterinarski Arhiv. 83, 223-232. 